\title{
INNOVATION AND TRANSFORMATION OF PRODUCTION COST CONTROL IN IMPROVING THE QUALITY OF AGRICULTURE RESOURCES AS AN ACCELERATION SOLUTION TO SUPPORT BUSINESS SECTOR AGRICULTURE DURING THE COVID 19 PERIOD IN INDONESIA
}

\author{
By \\ IGP Ratih Andaningsih \\ Faculty of Economic, University Of Borobudur \\ Email : ratihiai@ymail.com, andaningsihratih@ymail.com
}

\begin{tabular}{l}
\hline \hline Article Info \\
\hline Article History: \\
Received:13-10-21 \\
Revised : 14-11-21 \\
Accepted: $25-11-2021$
\end{tabular}

Keywords:

Inovation, transformation, Controlling, Business Industry, Agriculture, Cost production

\begin{abstract}
This research analyses development of innovation agroecology and innovation socio economy business conditions in Indonesia. The agriculture needs agriculture controlling report of cost production and tools and machinery support and solution with certain characteristics. The transformation business practically development of innovation business industry of agriculture materials is one of the efforts to improve competence and skill. The purpose of this study is to find out solutions practice in agriculture mechanicsm in busines sector industry, administration agriculture aspect and management of busines agriculture sector of skill and knowledge and its impact on the role of innovation and technology system in business agriculture area in controlling of cost production. This research uses descriptive qualitative and qualitative content analysis approach in busines agriculture sector industry area with 30 respondents, because there are multidisciplinary sciences in researching this research. This research has an impact on post pandemic Covid 19 in Indonesia. The limitation of this research is the increasing innovation and transformation agriculture mechanicsm and solutions in accelerated and supporting business industry of agriculture sector in Pandemic Covid 19 in Indonesia. The contributions of this research are that business industries of agriculture are able to maintain skill and knowledge of controlling cost production and innovation and transformation technology of agriculture busines sector.
\end{abstract}

Thisisan open accessarticleundertheCC BY-SAlicense.

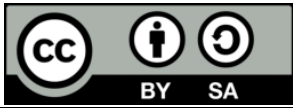

CorrespondingAuthor:

IGP Ratih Andaningsih

Faculty of Economic,

University of Borobudur

Email : ratihiai@ymail.com, andaningsihratih@ymail.com

\section{INTRODUCTION}

Indonesia has a wealth of natural resources and very high biodiversity. One of the reasons Indonesia is considered an agricultural country is because the agricultural sector is one of the leading sectors in the economy in Indon (Food-Leading agricultural country, 2011). Agriculture is a business activity which covers the activities of cultivating forage crops, holticulture, plantation, fishery, forestry and animal husbandry. Sustainable agriculture development requires reliable innovation and transformation in the field of technology and is supported by accurate and reliable control of production costs, especially during the Covid 19 pandemic. The spirit of innovationespecially in business transformation and agricultural technology supports agricultural production activities in terms of the agricultural sector business enterprises, which have 
been recognized as an important factor in the process of agricultural development (Bergevoet et al, 2005; Mc Elweedaan Bosworth, 2010). The spirit of cultivation and confirmation of the agrobusiness industry, the agriculture sector has made a positive contribution to the development of agriculture products in growing a prosperous huduo (Marsden dan Smith, 2005). The use is a very prestigious sector because it is very much needed by the community, but the current condition of agriculture is still less attractive to the younger generation because there is still a stigma that agriculture is poor and does not provide certainty for life. Actors in the future, agriculture is a very heteregeneous sector in which farmers operate in a complex environment with a variety of unique problems of appropriate mechanicsm greatly affects the success of agricultural production processes. The use of the right mechanicsm greatly affects the success of the agricultural production process. Agricultural is a very prestigious sector because it is very much needed by the community but this condition becomes a barrier for farmers, especially those who carry out the busines s activities of the agricultural industry (Carteobusinessr, 2003; McElwee, 2008a). The Covid 19 outbreak that has hit 215 countries in the world presents its own challenges for the agricultural agro business industry, especially in other big cities. The global challenged that emerged in late 2019 and is direct, today is the emergence of a global pandemic, namely the outbreak of the Chinese Virus, better known as Covid 19. Corona Virus (CoV) is contagious. In March 2020 the Covid 19 outbreak might remind them of several previous crises, such as the 2008 financial crisis and the 2008-2012 global recessions. Corona viruses (CoV) are antagiousdesease. In March 2020 World Health Organization (WHO), the world health organization states that the Covid 19 outbreak is a global pandemic. Not only in Indonesia, but almost all countries in the world have implemented a "Lockdown" policy. For many people the world is currently experiencing a crisis due to Covid 19 which may remind them of several previous crises, such as the 2008 financial crisis and the 2008-2012 global recession 2008-2012 (Shandy Pradana, 2020). The Covid 19 Pandemic is the first health crisis in the world. Interntional organizations headquartered in New York, United State of America reveal that one of the sectors affected by the Covid 19 pandemic is the businesses sector including agribusiness, agricultural products and small and medium sized industries, especially in the agricultural sector. The agricultural sector as a food producer is also affected by the negative impact of the Covid 19. The Current pandemic is forcing traders, processors, agricultural business entrepreneurship and other agrobusiness procurements to decreased produvtivity, for example disruption of distribution and marketing facilities for agricultural products is accompanied by a decrease in the welfare of farmers, Utami (2020). Based on the ABC news report on March 7, 2020, many countries were affected by the impact of the agriculture business industry due to the covid 19 out break, according to data from the UN Scientific and Culural Organization (UNESCO). According to Kompas on March 28, 2020, the impact of Covid 19 occurred in various fields such as social, economic, agro business industry, tourism and education. Directly the crisis due to this pandemic has reshaped people perpective on the behaviour patterns of the agricultural industry outside the home or in the world. Companies or home based businesses, especially in implementatting a business system of innovative agricultural products independently, and traditionally. Howefer behind some of the negative impacts during the crisis, such as this time it also presents several opportunities such as the use of sophisticated and flexible technology through other online digital system facilities and infrastructure and transformations. Other advanced agricultural machinery technology. The use of machine and mobile networking technology has a major contribution to the transformations of agricultural products in order to reduce the cost of production of agricultural products. The purpose of this research is to find out the practical solution of innovation and transformation in the field of agricultural business, an administration of agricultural, management of skills and to find out the level of satisfaction of agricultural industry actors, especially related to the use of digital technology facilities and control of agricultural production costs.

Table of Content

\begin{tabular}{|l|l|}
\hline No & Description \\
\hline & Agricultural technology development innovations. \\
\hline 1. & $\begin{array}{l}\text { Increasing the quality of agricultural products through the results of } \\
\text { agricultural technology transformation. }\end{array}$ \\
\hline 2. & The use of mecanica machines to accelerated the results of quality and \\
\hline 3. &
\end{tabular}


International Journal of Social Science (IJSS)

Vol.1 Issue.4 December 2021, pp: 361-372

ISSN: 2798-3463 (Printed) | 2798-4079 (Online)

DOI: https://doi.org/10.53625/ijss.v1i4.513

\begin{tabular}{|c|l|}
\hline 4. & $\begin{array}{l}\text { integrated agricultural production } \\
\text { technology transformation, agricultural machine technology } \\
\text { transformation and agricultural land management. }\end{array}$ \\
\hline 5. & $\begin{array}{l}\text { Controlling production costs to accelerated the production of optimal } \\
\text { and maximum agricultural products to achieve maximum profit } \\
\text { expand the network of agricultural agrobusiness and } \\
\text { entrepreneurship both traditionally and digitally to expand the } \\
\text { small,micro and medium enterprises sectors }\end{array}$ \\
\hline & \\
\hline
\end{tabular}

Indonesia has been developing agricultural mechanization for a long time, especially in the last 5 years, where many types of new equipment were distributed, especially land processing tractors, planting tools and other rice production harvesting tools in combinations (Rice transplanter) and (rice combine harvesyer). The introduction of machinery in agricultural has been carried out since independence but there have been many in effectiveness. This reflects the so called premature mechanization. The love of the process of introduction of agricultural machinery which is often followed by the readiness of certain institutions. An example from a previous study by RizmaAldillah regarding the use of agricultural mechanicsm is that the distribution of agricultural machinery assistance nationally has shown a large increase in revenue, especially since the program to accelerate the production of rice, corn and soybeans. According to data from BPS (Central bureau of statistics) and PSP in Indonesia processed in 2019 shows that the average growth of the Alsintan assistance program before uspsusprpgram for tractors, water pumps and rice planters is in the range of ran $21-128 \%$ and increased in the 2019-2020 period to $89-1.245 \%$ per year. According to Olm Stead and Rhode (2014) mechanization is the involved the replacement of simple hand tools and human power by more complicated machinery powered by animals, fossil, fuels and electricity. Conceptually, agricultural mechanization is the process of introducting and using mechanical assistance to carry out agricultural operations. The agricultural mechanicsm in the broadest sense aims to increase land productivity, and reduce productions costs. The use of tools and machines is also intended to increase efficiency, productivity, yield quality and reduce the spellin burden of farmers. Experience from Asian Countries shows that the development of agricultural mechanization begins with land management (land consolidation) as well as input of sociological technology and chemical technology. It adapted to the conditions and agricultural characteristics. Incontras to Japan, which made modifications according to local conditions and then produced their own products for use by local farmers (Mangunwijaya and Saillah, 2005). Some of the advantages of the farming mechanicsminclude: increasing production per unit area, income due to additional production, increasing effectiveness, productivity, quantity and quality of agricultural products, maintaining the quality and quality of fresh handling products, increasing added value of agricultural production, saving and reducing cost. Production of agricultural products, preserving the environment and production of agricultural products. And internal rate of Return (IRR) such as in the practice of implementation that has been carried out by Subagyo (2016), as Alsintan has already fulfilled the farmers needs. The benfit of Alsintan utilization are shown from the use of other tools such as the planting of rice porridge which is carried out in the irrigation. On research study with this tool used the mekongan variety with a spacing of $30 \times 18 \mathrm{~cm}$ in Plosorejo, Sragen Regency 9Central Java Province) in MT I andMT II were proven to be able to increase productivity by $16.13 \%$ and $17.14 \%$ respectively. The results of others studies using the inpari I variety were able to increase productivity by $30 \%$ compared to the $20 \times 20 \mathrm{~cm}$ tile system 9 Suhendra et al 2012).

\section{THEORETICAL BASIS}

In recent years, agro industrial business players have realized how important the spirit of innovation and transformation is to do business in the agricultural business industry. Mc Elwee (2006) states that agriculture must begin to specialized and diversify effectively and selectively based on market demand that ie well managed (Well managed). So they have not had a career in agricultural not because they are not experts in the field and in it, but precisely because they really understand agriculture (Mukti Gema, 2017). This phenomenon becomes very interesting when educated personnel are expected to advance the agricultural sector. Shillus (2014) states that quality development can be achieved witf effort and hard work through 
education for the true entrepreneurial spirit carried out by the community. The strategic position of Agricultural mechanization has a very complex meaning. For Indonesia because it contains many benefits ranging from increasing production, reducing losses in the harvest process, reducing agricultural production costs and expanding and increasing cropping intensity (BBP Mektan, 2016). Many countries have developed agricultural mechanization but varyng successes are interesting to observe on the fairness of the agricultural business itself. The results of Handaka's research (2012) found that the contribution of using Alsintan in Agricultural development can be measured in various cases, for example the use of Alsintan in agricultural development can be measured in various cases. For example the uses of a groundwater pump in East Java which is able to change the cropping pattern from Bero rice to paddy and secondary crops. Like wise, the use of a rice thresher machine is able to reduce the harvest loss from $75 \%$ to less than $2 \%$. Research shows that there are improvement and although rice milling is able to increase milled yield. On Country that has been quite successful in mechanizing agriculture is South Korea. This country has been developing mechanization for approximately 50 years where the development of rice farming has been quite seccesfull and complete but for horticulture and lice stocks are being developed (Kim 2009). Small scale farming is not an inhibiting factor as I China. China also faces problems of land tenure, and increasing wages of agricultural laborers, especially for harvesting activities (Zhang, 2017). Small can still maintain their competitive power by sourcing labour and power intensive steos productions to others, smallolder farmers can maintain their competitivenessdespite their small and fragmented land suze. However as the current old generation farmers with low opportunity cost of labour die out in the near futureland consolidation will become inevitable (Zhang, 2017). The problems in Turkey are the same, namely the scale of small and medium enterprise and fragmented land (Akedmir, 2013). Other research shows that the average income level of rice farming has increased after the use of ALsintan (Hermanto et al, 2016). Increased income is the accumulation of increased productivity of agriculture rice and reduced losses in non labour cost expenditures to be smaller meaning that it is able to reduce production cost optimally and use of labour both directly and indirectly. Research by (Saliem et al 2015) found the same thing. The use of Alsintan in a fairly wide expanse provides benefits in the form of time savings. Reducing the use of labor, reducing crocodiles, increasing productivity. He yields loss at harvest ranges from $10-12 \%$ with the use of a combine harvester which can be reduced to 3-5\%. Another benefit of the modern technological transformation of agricultural machinery is reduced agricultural production overhead cost and reduced yield loss compared to conventional farming which is coomonly practiced by farmers. The use of Alsintan can increase production from 8.6 to 12.8 tons/ha. The yield loss at harvest ranges from $10-12 \%$ with the use of a combine harvester which can be reduced to 3-5\%. Another benefit of the modern technological transformation of agricultural machinery is reduced agricultural production overhead cost and increased income for farmers. Various research results have shown a decrease in production costs and variable overheads and fixed overheads especially labor costs due to using advanced technology machines. Research from 345 units of farming and livestocks and agrobusiness in the greater Jakarta area and its surroundings, especially beef and poultry farms and diversifications of crop agrobusiness results, incur higher gross costs and require higher mechanization costs. Greater is not compensated by a higher gross margin (Miserque, 2015).

\section{METHODS}

The research was conducted using a qualitative method approach with content analysis and qualitative descriptive methods with indepth long distance surveys and interviews with WA Japri using key informance and researchers wanted to analyze messages to be able to observe and analyze the behaviour and activities of certain subjects related to the solution of farming mechanicsm practices in industrial business,agricultural administration and skills and knowledge of farming in the agricultural sector and their impact on the role of innovation and technological systems in the agricultural sector in controlling agricultural production costs in the Jabodetabek area. According to Fraenkel content analysis is a technique that allows researchers to studyng human behaviour in an indirect way through analysis of the attitudes and behaviour of the subjects in interacting or communicating either directly or indirectly (Fraenkel, 2006). Content analysis is a systematic technique for analyzing message content and processing messages or a tool for openly observing and analyzing behaviour attitudes of the chosen communicator (Budd in Kriyantono, 2012:232). Research with content analysis uses data in the form of written documents,audiovisual or video recordings of 
International Journal of Social Science (IJSS)

Vol.1 Issue.4 December 2021, pp: 361-372

ISSN: 2798-3463 (Printed) | 2798-4079 (Online)

DOI: https://doi.org/10.53625/ijss.v1i4.513

experiments, observations, surveys and secondary data(Cooper and Schindler, 2014). According to (Krippend off, 2004), a qualitative descriptiveapproach,namely with data obtained through searching google scholar by searching" Transformation of agricultural business during the Covid 19 pandemic and industrial revolution 4.0 and qualitative using the contents analysis method have an alternative way to explore data, namely exploring how reality is accounted for in interactions between humans and in language including written text. The data presented in qualitative research is in the form of words that can describe and provide detailed explanations of the results of in depth interview research. Data collection was carried out by interview techniques through remote interviews via WhatsApp JApri and zoom cloud meetings with agrobusiness enterpreneurs and representatives of farmers in Indonesia. Rural areas namely BojongKulur Village Gunung Putri Region, Bogor Regency West Java and supporting data analysis also uses the Miles and Huberman analysis model (1994) which consists of 3 stages namely data reduction data display and verification.

Data Reduction

Analysis of research data in the reduction stage is the stage of collecting all the information needed from the results of long distance interviews which grouped the data. The data display stge is the exsposure of data that is needed in data research and which does not need to be discarded and Huberman M, 1994).

The Focus and analysis used in this study emphasizes:

The focus and analysis used in this study emphasizes: to find out the level of satisfaction and solutions for agricultural product industry and agricultural product ibdustry and agricultural administration and management of agricultural business skills and knowledge as well as the role of innovation and technological systems in the agricultural business sector ibn controlling agricultural production costs.

The first research question aim to find out the level of satisfaction with agricultural industry sectors on the use of modern agricultural technology in improving and optimizing business results and being able to reduce and control agricultural production costs efficiently and effectively and on target. How can innovation in the development of agriculture production mechanicsm in utilizing agricultural technology control production costs for the purpose of optimal results properly and effectively? Research questions airm to see how far these agricultural business sectors are satisfied with the mechanical technology currently being used, especially the industry actors in agricultural business agro business sector and other large companies. The assessment will be based on the principle of triangulations in which data one and the other are unbiased and interrelated with each other. The data for related activities are obtained from books or literatur, media reports, journals articles and other research results.The problem to be solved or the object in this rsearch is a arealrelated to innovative efforts and transformation of the agricultural business for the purpose for controlling the production costs of agricultural products of agricultural in an optimal, efficient and effective manner whose results are expected to be felt by the wider community in Indonesia.

The population in this study are:

1. The representatives of farmers in the Bojong Kulur Bogor West Java

2. Agro business actors in the agricultural sector, livestock in the Bogor area and its surroundings.

3. Small,micro and medium agrobusiness actors in the Bogor and surroundings areas.

\section{Data Collection Techniques}

The data analysis technique used in this study is quantitative data analysis following the concepts given by Miles and Huberman and Soradley, Miles and Huberman (Sugiyono, 2013:183) suggesting that activities in qualitative data analysis are carried out interactively and take place continuously. Continously at each stage of the research and the data until it is clear. Activities in data analysis are data refucting and display and conclusion and verification. 
Picture 1

Data analysis and survey verification

Data coll
I
I
I
V

Data analysis ----------------- $\rightarrow$ Conclusion

\section{Source: Sugiyono (2013)}

Data credibility analysis

According to Sugiyono (2013) testing the credibility of research data will be carried out by:

- Extending observations

- Increasing diligence and checking

- $\quad$ Checking

\section{RESULTS AND DISCUSSION}

The agricultural sector industry became a breakthrough during the Covid 19 Pandemic.Several Other sectors affected by Covid 19 Such as the tourism sector, automative, construction and other infrastructure and the financial sector experienced a significant decline Protecting the workforce and improving solutions for agriculture product cultivation innovations and reducing production costs are the main targets in conducting business survival innovation and transformation during the current covid 19 Pandemic. The increase in internet use in Indonesia is influenced by the development of information and communication technology (Rahadian D,2017).In 2018 there were around 62,41\% of the Indonesian population already had a cellular telephone and $20.05 \%$ of households had a computer at home (BPS, 2019). There is an increase in the percentage of mastery of science process skills, material understanding and scientific attitudes as results of Suci's research (2008)

Table 2

Respondent

\begin{tabular}{|c|l|c|}
\hline No & \multicolumn{1}{|c|}{ Informant (Agricultural business actor in Jabodetabek area) } & Amount \\
\hline 1. & $\begin{array}{l}\text { Representative of farmers in the BojongKulurRegion,BogorBekasi,West } \\
\text { Java }\end{array}$ & 10 \\
\hline 2. & $\begin{array}{l}\text { Agro business actors in the agricultural sector,livestock in the Bogor } \\
\text { area and its surroundings }\end{array}$ & 12 \\
\hline 3. & $\begin{array}{l}\text { Actors in the agro business MSMEs in the Bogor area and its } \\
\text { surroundings }\end{array}$ & 30 \\
\hline & Number of respondent & \\
\hline
\end{tabular}

Data source: Data processed by researchers

Research results obtained in the field using survey interview techniques to 30 respondents or informants

Table 3

Respondent's answer

\begin{tabular}{|c|c|c|c|c|c|c|}
\hline No & Name & Questions & & & & \\
\hline & & 1 & 2 & 3 & 4 & 5 \\
\hline
\end{tabular}


International Journal of Social Science (IJSS)

Vol.1 Issue.4 December 2021, pp: 361-372

ISSN: 2798-3463 (Printed) | 2798-4079 (Online)

DOI: https://doi.org/10.53625/ijss.v1i4.513

\begin{tabular}{|c|c|c|c|c|c|c|}
\hline \multicolumn{2}{|c|}{$\begin{array}{l}\text { Representatives of } \\
\text { farmers in the } \\
\text { BojongKulurRegion,Bogor } \\
\text { Bekasi WestJava }\end{array}$} & & & & & \\
\hline 1 & Joko & No & Yes & Yes & Yes & Yes \\
\hline 2 & Sulistry & No & Yes & Yes & Yes & Yes \\
\hline 3 & Bangun & No & Yes & Yes & Yes & Yes \\
\hline 4 & Dede Suhedar & No & Yes & Yes & Yes & Yes \\
\hline 5 & Jimun & No & Yes & No & Yes & Yes \\
\hline 6 & Djemingan & No & Yes & No & Yes & Yes \\
\hline 7 & Edi & No & Yes & No & Yes & No \\
\hline 8 & Satiman & Yes & Yes & Yes & Yes & No \\
\hline 9 & Sulistyo & Yes & Yes & Yes & Yes & No \\
\hline 10 & Sani & Yes & Yes & Yes & Yes & Yes \\
\hline $\begin{array}{l}\text { Agr } \\
\text { the } \\
\text { sec } \\
\text { Bog } \\
\text { sur }\end{array}$ & $\begin{array}{l}\text { Dusiness actors in } \\
\text { ricultural } \\
\text {;livestock in the } \\
\text { area and its } \\
\text { undings. }\end{array}$ & & & & & \\
\hline 11 & Wati & Yes & Yes & Yes & Yes & Yes \\
\hline 12 & Doni & Yes & No & Yes & No & Yes \\
\hline 13 & Ujang & Yes & No & No & No & Yes \\
\hline 14 & Didin & Yes & No & No & Yes & Yes \\
\hline 15 & Sutarman & Yes & No & No & Yes & Yes \\
\hline 16 & Keli & Yes & No & Yes & Yes & Yes \\
\hline 17 & Doni & Yes & Yes & Yes & Yes & Yes \\
\hline 18 & Jimi & Yes & Yes & Yes & Yes & Yes \\
\hline 19 & Jono & Yes & Yes & Yes & Yes & Yes \\
\hline 20 & Deden & Yes & Yes & Yes & Yes & Yes \\
\hline
\end{tabular}

\begin{tabular}{|c|c|c|c|c|c|c|}
\hline 21 & Dudu & No & No & Yes & Yes & Yes \\
\hline 22 & Chandra & No & No & Yes & Yes & Yes \\
\hline \multicolumn{7}{|c|}{ Actors in the field of agribusiness SMEs in The Bogor area and its surroundings } \\
\hline \multicolumn{7}{|c|}{ The Number of respondent } \\
\hline 23 & Ratna & No & Yes & Yes & Yes & No \\
\hline 24 & Ibu Wika & Yes & Yes & Yes & No & No \\
\hline 25 & Ida & No & No & No & No & Yes \\
\hline 26 & Yuli & Yes & Yes & Yes & No & No \\
\hline 27 & Winda & Yes & Yes & Yes & No & Yes \\
\hline 28 & Susi & No & Yes & Yes & Yes & Yes \\
\hline 29 & Eki & Yes & Yes & Yes & Yes & Yes \\
\hline
\end{tabular}




\begin{tabular}{|lllllll|}
\hline 30 & Elsa & Yes & Yes & Yes & Yes & Yes \\
\hline
\end{tabular}

Data source: Data processed by researchers (May 2021)

Interview data points:

1. Has the innovation of farming technology development been carried out properly and satisfactorily in your respective residential locations?

2. Has improving the quality of agricultural products through the transformation of agricultural technology results been carried out properly?

3. Has the use of mechanical machines to accelerated the results of quality and integrated agricultural production run well and satisfactorily?

4. Has the harmonization between the use of digital machine technology,digital technology transformation,machine technology transformation and traditional and traditional transformation and agricultural land management machines going well and satisfactorily?

5. Is the control of production costs to accelerate the optimal and maximum production of agricultural products to achieve maximum profit has beengoing well and satisfactorily?

Is it possible to expand the network of traditional agricultural agribusiness entrepreneurs and to expand the small,micro and medium business sector already running well and satisfactorily?

From the results of the survey, it is shown that for the first survey, which shows a $60 \%$ level of satisfaction with agricultural technology development innovations with agricultural technology development innovations in the Greater Jakarta area and its surroundings, especially in the Bekasi, Bogor and surroundings areas.For the results of the secondpoint survey, it shows a 73\% satisfaction level for improving the quality of agricultural products through the transformation of agricultural technologyproductstht have been carried out well.Untuk point survey .For point survey questions number 3 shows a satisfactions level of $76 \%$ using mechanical machines to accelerate quality and integrated agricultural production results have been running well and satisfactorily outside of other agricultural technology supporting facilities. For the point survey question number 4 shows 80 levels of harmonization between the use of machine technology, digital, digital technology transformation,machine technology transformation and traditional transformation and agricultural land management machines have been running well and satisfactorily.And for questions point 5 shows $80 \%$ control of production costs for accelerating the optimal and maimum production of agricultural products to achieve maximum profit has been running well and satisfactorily and can expand the network of agricultural agribusiness enterpreneurs both traditionally and digitally to expand the small,micro and small business sector which can already run well and satisfactorily.

For the informants who represent this research in the Jabodetabek:

\begin{tabular}{|l} 
1. \begin{tabular}{l} 
Representatives of farmers in the \\
BojongKulurRegion,Bogor,Bekasi West Java as many as 10 \\
informants consisting of 6 farmers working as pure farmers in \\
collaboration with local farmer cooperatives and 4 people who \\
are impure farmers who are suppliers of agricultural \\
agribusiness industry micro and medium. \\
\hline 2. \\
Agrobusiness actors in the agricultural sector,livestock in the \\
Bogor area and its surroundings were 12 informants consisting \\
Bogor Tapos and surroundings areas and 2 gold fish and catfish
\end{tabular} \\
\hline
\end{tabular}


International Journal of Social Science (IJSS)

Vol.1 Issue.4 December 2021, pp: 361-372

ISSN: 2798-3463 (Printed) | 2798-4079 (Online)

DOI: https://doi.org/10.53625/ijss.v1i4.513

breeders.

3. There are 8 informants in the field of MSME Agrobusiness in the Bogor region and its surroundings,namely 6 business people of ornamental and home based plants (home industry) and 2 business people of fruit and vegetable Agrobusiness,which are sold in traditional markets.

In the current conditions, especially the Jabodetabekarea, the massive and rapid spread of the Covid 19 virus requires a fast and appropriate response. One of the efforts made by the Indonesian government is the large scale social restriction (PSBB). Runs smoothly and is able to reduce the negative impact on the farming business industry. Several International institutions project that the global economy will experience a contraction of minus 4.9\% (IMF 2020),-5.2\% (World Bank 2020b). Especially in the agricultural sector, large scale restrictions in Indonesia, especially the JAbodetabek area, have very wide impact.Yusuf et al (2020) believe that the agricultural sector is a natural social safety net by absorbing more workers during the Covid 19 pandemic. Broadly speaking a few things that need to be fully alerted:

- Health factors of agricultural businesses and agricultural agribusiness live stock and other agricultural business actors.

- $\quad$ Availability of production facilities and food distribution channels

- $\quad$ Production process and agricultural business development by farmers.

- $\quad$ Distributions of agricultural and other agrobusiness products.

- Consumtion of products agricultural and other agribusiness

- Consumtions of agricultural and agrobusiness products concern food security and people's purchasing power as a form od adaption to the Covid 19 pandemic situation that occurs in demand patterns and agricultural product distribution systems.Society as aresult of theweakening of the economy and increasing unemployment. In the upper middle income class there is a shift in consumtion patterns to healthy food while in the lower middle income class it leads to carbodydrateconsumtion so that it affects the diversifications of agriculturalindustry results .

Farmings agribisnis subsystem, West Kalimantan TPH Distan (2020) in early April 2020 carried out a mapping of the impact of Covid 19 in the Agricultural sector and stated an appeal to stay at home in farming activities even though there were still farm products, especially distribution system and online retail marketing methods. Permani et al (2020) noted an increase in the number of transactions for agricultural products through e commerce system. The dominance of the millennial population in the population structure is a positive opportunity for the development and development of food e commerce in Indonesia working in the fields and activities on agricultural land but the number limited changes and business transformation of food demand patterns encourage innovation of value chain system for agricultural products. As for the challenges of innovation and development of agricultural business transformation in the context of controlling agricultural production costs during the Covid 19 periode, the government has not yet found an effective method of overcoming the spread of Covid 19 related to innovation and transformation. In such conditions the potential for healths levels and the food chain still exist and instead increasing so that the threat of food scarcity conditions persist (Petetin 2020). This condition adds to the challenges of innovation,business development and transformation in the agricultural sector related to the limited number of quality human resources in agriculture,especially land and water whose demands continue to increase due to the increasing number of people population. One of the lessons learned from this pandemic is readiness and adaptability to adapt to conditions and create opportunities for the problems encountered. Export restrictions for trade clousures. Disruptive changes are felt to occur in the pattern of transactions and distribution of agricultural products. Consumers who are more, and digitally. The researchers strongly support the Indonesia governments program during the current covid 19 pandemic namely by adapting and innovating through the development of a social safety net (Social safety net) for farmer workers and sharecroppers, smallscale, development of agricultural sector job creation programs using sophisticated agricultural machinery such as modern Alsintan,other agricultural sector labor intensive activities,stimulations of agricultural production with business assistante including tools and equipment.Agriculturalmachinery,assistance for production 
facilities and development of irrigarion facilities to increase the cropping index and acticipation of the dry season and assistance with distribution and marketing programs by providing transportation costs assistance and developing retail farming businesses or farmer markets for marketing agricultural production.In accordance with the mandate of law No 23 in 2014 concerning regional government, regional authority becomes grater in regional economic development, especially the greater Jkarta area and its surroundings and other regions in Indonesia. The amount of funding for the implementation of deconcentration and assistance tasks so as to accelerated the realization of community welfare through service improvement, empowerment and community participation (Siagian 2016). In the context of agricultural development, the program implementer in the field is the local government.Increasing the involvement andresponsibility of local government in Indonesia in the development of prophecy is very important (Winoto and Siregar 2008). Article 24 of Law No 23 of 2014 concerning regional government.The region mandates that for business. The Ministries/institutions with the regional government carry out a mapping of mandatory government affairs that are not related to basic services and selected government affairs that are prioritized by each province and city district (Siagian 2016). The transformation of development and innovation of agrobusiness technology in an effort to reduce the cost of production of agricultural products in the future and must learn from the current Covid 19 Pandemic, considering that development management must include and able to follow the dynamics of changing agrobusiness in the current industrial sector which is developing from upstream to down stream. It is very necessary to develop facilities, infrastructure, tools and machine as well as appropriate technology and administrative and accounting systems in the field of sophisticated and modern production and overhead costs that are good and integrated that supports the agricultural business sector especially in agricultural management governance that is more flexible and responsive to the development of the agro business industry in the future. For the transformation of the field of agricultural business communications services, farmers usually use digital networks such as using cloud agrobusiness facilities, zoom meetings, whatsapp, or other digital system access that supports activity facilities their agricultural business, for example the launch of technology such as Sygenta in Indonesia that can be useful for plant protection networks and new types of superior rice seeds and corn seeds. Another type of plant protection that utilizes plant protection technology is touchdown neo orondisopti. Touchdown neo is a technology in the herbicide category that can help farmers overcome challenges in weed management due to labor shortages and cost efficiency in agricultural production. Meanwhileorondisopti is he lates technology in the fungicide category for the control of phytophthora disease in tomatoes and downy mildew on cucumber plants. This technology is a solution for tomato and cucumber farmers in maintaining yields and harvest quality so that they can be accepted by foreign and foreign markets.

\section{CONCLUSION}

Based on the explanation above, the conclusions of the overall research results are:

1. There is demand for mastery of technology,innovation and transformation of agricultural business,especially in the field of agrobusiness and agricultural as a whole,involving the local government, the central government in icreasing the resilience of agricultural production in remote learning communities in an efficient and effective manner, especially in the contek of controlling production costs and improve the standars of living of farmers and micro and medium industry agrobusiness in Indonesia in general and the Jabodetabek area in particular during the Covid 19 pandemic and must follow and comply with health protocols whereever they work at home or in the field.

2. Based on the results of this qualitative research method, the impact of Covid 19 is currently expected to make a major contribution to regional farmers and traders in the agrobusiness industry in an effort to create jobs in a better and prosperous future through innovation and transformation.Up to date and renewable technology that is beneficial for the agricultural business and the wider community which is labor intensive and absorbs labor and is able to increase the productivity of agricultural production in a productive and sustainable manner.

\section{Research Limitation}

This research is limited to: Measuring the level of satisfaction and practical solution of agricultural mechanicsm in the field of industries business, administration of agricultural and management of skills and knowledge of agricultural business as well as the role of innovation and technology sytems in the field of agricultural business in controlling agricultural production costs.

\section{Suggestion}


International Journal of Social Science (IJSS)

Vol.1 Issue.4 December 2021, pp: 361-372

ISSN: 2798-3463 (Printed) | 2798-4079 (Online)

DOI: https://doi.org/10.53625/ijss.v1i4.513

1. It is better to carry out a technological transformation system in the field of agricultural tools and machinery with the aim of controlling agricultural production costs,so that it is more effective and efficient in the context of creating renewable modern innovations to improve the quality of agricultural production with the use of modern machinery with the aim of reducing and controlling production costs optimally and is expected to be able to increase income for rice farmers and other agribusiness such as vegetable farmers,cattlebreeders,gold fish and catfish farmers and other agr

2. Cultural products industries such as medicinal and other traditional plants,especially to supports the prevention of Covid 19 and to maintain natural health and fitness oprimal in Indonesia.

3. There is a need for concern from the government and related institutions to improve machine facilities or procucheap and affordable renewable agricultural machinery support for rural farmers,especially for the easternpart of Indonesia and its srroundings (for example the use of renewable machine tools of the type of Alsintan supported by facilities from the government others) the goal is to equalize the standards of living of rural farmers throughout Indonesia and increase income for better and more optimal rural areas.

4. Considering that this research is far fromperfect,it is hoped that further research will be carried out toperfect this research and it is also hoped that it can make a useful contribution to the agricultural agrobusiness sector and especially MSME business activities in rural and Jabodetabek areas, and the Indonesian territory in general.

\section{Research Implication}

This research is expected to make a positive contribution to the development of practical solutions in the field especially the development of technology and business transformation of research results in the fields of business,industry and I particular administration and accounting of controlling productions costing in agricultural and managing skills and increase knowledge of agricultural business and its impact on the role of innovation and technological systems in the field of agricultural business,especially in the field of controlling agricultural production costs in the Greater Jakarta area and the territory of Indonesia in general as well as the eastern part of Indonesia and its surroundings.

\section{Thank You Note}

I am very grateful to God Almighty who has given me the grace and grace so that I can complete this research.And I thank Tarlac Agriculture University for giving me the opportunity to support this research.

I also thank the farmers, MSMEs business activities representatives from the Bogor and Bekasi areas who are representatives of informants in this qualitatives research method who have supported me.

\section{REFERENCE}

[1] Akdmir B (2013). Agriculture mechanization in Turkey 2013.IERI Procedia. 5:41-44

[2] Almentaire (2020).Covid 19:Availabele from: https://www.proceslimentaire.com/viedes-iaa/covid 19

[3] Ananto EE,T Alihamsyah (2012). Agricultural mechanization development,success and problems in:Indonesia's food independence in perspective MP3EI.Jakarta (ID):IAARD BBP MEktan(2016). Final report on theTangerang (ID): Center for the development of agricultural mechanization

[4] Study of agricultural mechanization strategies in agriculture development with an agrobusiness perspective,

[5] BPS, Central Bureau Of Statistics(2020). Indonesian economy quarter II 2020 decrease 5,32\% (Internet) Jakarta (ID) BPS downloaded 2020

[6] FAO,Food And Agriculture Organization of United Nations(2020) Responding to the impact of theCovid 19 outbreak on food value chains through efficient logistics (Internet)

[7] Gray RS(2020) Agriculture,transportation, and the Covid 19 crisis,Can J Agric Econ (Internat)

[8] Handaka (2012) Contribution of agricultural mechanization and post harvest technology to agrobusiness systems and businesses.Papers on expose and seminars on post 2002 agricultutalmechanizationa and technology 2002 Jul 30-31 .Malang Indonesia.

[9] ILO,InternastionalLabour Organization(2020) Covid 19 and gheir impact on agricultural and food security (Internet) Jakarta ID) ILO Jakarta (Diunduh 2020)

[10] OECD The Organisation for Economic Co operation and Development (2015).Frascaimanual:proposed standard practice for surveys on research and experimental development (Internet) 6 th ed. Paris (FR):The Organisastion for Economic Co Operation and development (Cited 2016 Jun 13).Available from: http://www.oecd .org/sti/frascatimanual.

[11] Patetin L (2020).The Covid 19 crisis:an opportunity to integrate food democracy into post pandemic food system Eur Risk Reg 11 (2):326-336 
[12] Saliem HP.Kariyasa K,Mayrowani H,AgustianA, FriyatnoS, Sunarsih (2015). Prospect for the development of modern agricultute through th use of agriculture mechanization technology in paddy fields.Policy analysis report.Bogor (ID):Center for Socio Economic and Agricultural Policy.

[13] Subagio (2016) Analysis of the financial feasibility of using Alsintan in rice farming in the special area of Yogyakarta,Yogyakarta.Agros 18(1):33-48

[14] Siagian E (2016).Embodiment of the implementation of government affairs in the agricultural sector, the role of ministry/regional government institutions.

[15] Yusuf AA,SugandaT,Hermanto.Mansur F HAdisoemarto P(2020). Agricultural sector economi strategy in the midst of the Covid 19 .Perspektif 2030 SDGs Center Policy Brief 2 (2020):1-8 